\title{
Subcutaneous Emphysema and Pneumomediastinum after Adenoidectomy; A Rare Complications
}

\author{
Alsaleh Sara, Alabidi Abdulaziz and Mohammed Gamal Aly* \\ Department of Otorhinolaryngology, Head and Neck Surgery, Johns Hopkins Aramco Healthcare, Saudi Arabia
}

Submission: December 26, 2018; Published: January 11, 2019

*Corresponding author: Mohammed Gamal Aly, Department of Otorhinolaryngology, Head and Neck Surgery, Johns Hopkins Aramco Healthcare, Saudi Arabia

Abstract

Subcutaneous emphysema and pneumomediastinum are an extremely rare complications of adenoidectomy. Although the majority of cases are self-limiting and benign, it may lead to life-threatening complications, such as tension pneumothorax. Symptoms include fever, neck pain, chest pain, dyspnea and odynophagia. We experienced a rare case in which subcutaneous emphysema and pneumomediastinum developed in a healthy 11 years old boy after adenoidectomy only, it was evident by clinical and radiological examinations. This case to our knowledge is the first case of subcutaneous emphysema and pneumomediastinum linked to adenoidectomy only in the English literature. Prevalence, possible pathogenic mechanisms and treatment options are discussed.

Keywords: Subcutaneous; Emphysema; Pneumomediastinum; Adenoidectomy

\section{Introduction}

Adenoidectomy is a common otolaryngological surgical procedure that is performed alone or in conjunction with tonsillectomy. Although the recovery following adenoidectomy is remarkably easy compared with the recovery following tonsillectomy alone or tonsillectomy with adenoidectomy, it is nevertheless associated with several complications, including hemorrhage almost always occurs in the first 24 hours following surgery rather than later [1-3], otolagia, dehydration, neck pain, tempromandibular joint dysfunction, velopharyngeal insufficiency and nasaopharyngeal stenosis [4-6]. In additions, the complications of subcutaneous emphysema and pneumomediastinum can also occur, albeit much more rarely. The latter complications were first reported in 1953 and have since that time been reported only very infrequently [7]. Although it is usually benign and self-limiting, it can result in significant morbidity and mortality without proper recognition and management. We reported a rare case of healthy 11 years old boy, developed subcutaneous emphysema and pneumomediastinum on the same day after adenoidectomy which were evident by clinical and radiological examination.

\section{Case Report}

An 11 years old male and his twin brother both were electively admitted for adenoidectomy for obstructive sleep apnea that didn't respond to medical treatment. The child was otherwise healthy and had no other significant medical history. Under general anesthesia with endotracheal intubation per oral, adenoidectomy was performed using curette and hemostasis was achieved. The surgical steps started after regular smooth intubation, Mouth gag was applied, and nasal catheter was inserted to retract the soft plate. Examination of nasopharynx by mirror revealed moderate adenoid hypertrophy. The adenoid removed by curette and hemostasis was achieved by suction diathermy, the surgical procedure progressed uneventfully. In the recovery room he was doing well apart from mild cough, stable vital signs, he was discharged on the same day. Few hours later at night the patient presented to the emergency room complaining of sever neck pain, stiffness and difficultly in swallowing. A physical examination revealed high temperature, no signs of airway, ventilatory or hemodynamic instability were evident. Laboratory findings included white blood cell (WBC) count of 21,000 cell/ $\mathrm{mm} 3$. A lateral neck $\mathrm{x}$-ray showed air leak to retropharyngeal and retromediastinum spaces, with no airway compromise (Figures 1 $\& 2)$.

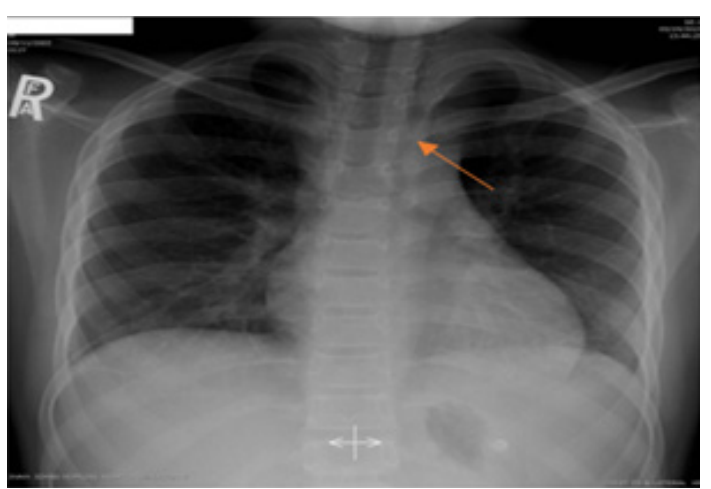

Figure 1: Posterior anterior chest $\mathrm{X}$-ray demonstrating a pneumomediastinum. 


\section{Global Journal of Otolaryngology}

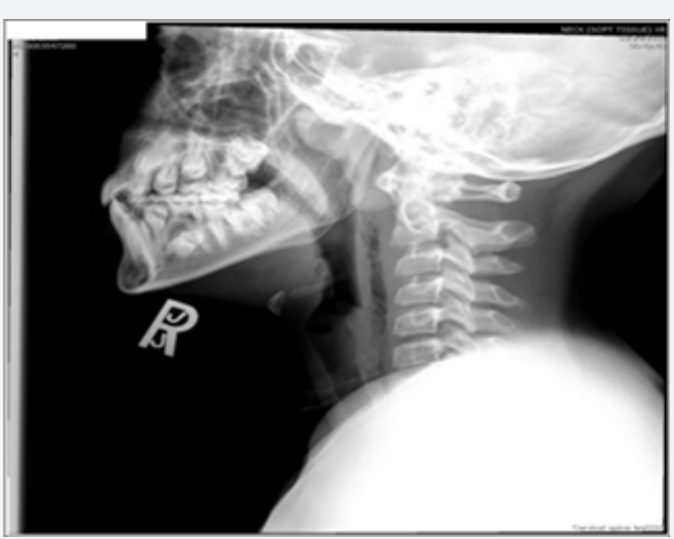

Figure 2: Lateral radiograph of the neck showing extensive free air in the retropharyngeal space.

He was admitted to the general ward for observation, started on analgesics and broad-spectrum antibiotic in a form of Imipenem, an infectious disease consultation was made. Neck computed tomography (CT) scan was requested and showed extensive retropharyngeal air collection that extend to the superior mediastinum (Figure 3). The anterior posterior diameter of the prevertebral soft tissue and soft tissue air is about $1.7 \mathrm{~cm}$, there was no evidence of pneumothorax. He was kept on nil per so diet and intravenous fluid was given for 2 days. Daily complete blood cells, C- reactive protein (C-RP) and repeated lateral neck $\mathrm{X}$-ray were arranged to follow. On the second day, he continued to have spiking fever, high WBC count and C-RP. On the third day, he started to improve slowly, his temperature came down also his WBC count and C-RP decreased. He was advanced to liquid diet and then soft diet; the antibiotic was shifted to per oral Augmentin. The patient was discharged with a good prognosis a week after the surgery. Up until now, follow up visits have found him to be in good health without any special findings.
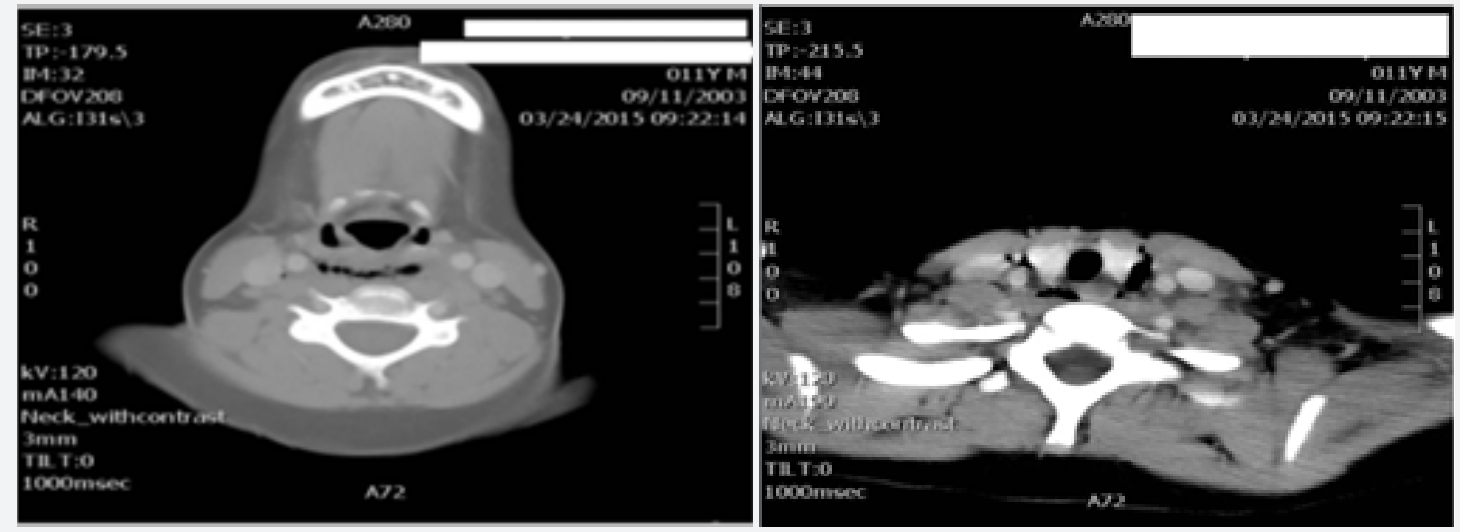

Figure 3: Axial CT of the neck showing air within the deep soft tissues of the neck from level of the hypopharynx down to the mediastinum.

\section{Discussion}

Subcutaneous emphysema rarely occurs in the neck and face during postoperative period. It can be caused by surgical or anesthetic procedure, such as maxillofacial surgical procedures, trauma, dental extraction, adenotonsillectomy, traumatic intubation, excessive positive pressure ventilation and excessive manual ventilation [8-12]. Proposed causes of air entry are: (1) mucosa disruption of the upper aerodigestive tract (descending route); (2) rupture of the marginal alveoli resulting from an excessive rise in intrapulmonary pressure (ascending route) [11]. In this case, there was no difficulty in endotracheal intubation, for that the most likely portal of egress of air into the soft tissues is from the adenoidal bed, as the mucosal integrity of the pharynx is breached secondary to the surgical procedure. From here, air may track in caudal direction following the deep cervicofascial plane to the parapharyngeal neck space. Since the paraphayrngeal and retropharyngeal spaces are connected anatomically, the air then travels to the mediastinum. Postoperative factors that may facilitate this include retching, vomiting and coughing by which a valsalva maneuver against a blocked oronasopharynx can force air through the mucosal breach with sufficient pressure to dissect through the soft tissue [13].
Subcutaneous emphysema is typically associated with crepitus, and the subcutaneous air can be detected immediately by radiological imaging such as X-ray and computed tomography. If the patient showing subcutaneous emphysema also has dyspnea, dysphagia, chest and back pain, cyanosis, and Hamman's sign (crepitus synchronous with systole), pneumomediastinum should be suspected [14]. In some rare cases, the air that has descended to the mediastinum may then descend further to the abdominal cavity via the diaphragmatic aperture $[10,15]$. We reviewed the English language literature via MEDLINE for all the reported cases of subcutaneous emphysema weather it's associated with pneumomediastinum or not following tonsillectomy and/or adenoidectomy. We found 29 reported cases, this includes both the pediatric and adult populations, the details of these cases together with the details of our case reported here are presented in (Table 1). Most of the reported cases were after tonsillectomy, our patient case considers as the first and only reported case of subcutaneous emphysema and pneumomediastinum after adenoidectomy alone in the English literature. Of the 30 patients including our patient, 13 were male and 17 were female. The mean age was 23.5 (age range, 4-55 years) [16-28]. It is observed to occur more commonly in adult patients, possibly because of more dissection needed in 


\section{Global Journal of Otolaryngology}

adults, with trauma to tissues and predisposition to mucosal tears both techniques were used, 1 case by bipolar diathermy alone and and dehiscence. Tonsillectomy was performed in 4 and 10 cases 2 cases by cold steel with bipolar diathermy.

by electrodessication and cold steel respectively and 1 case which

Table 1: Reported cases of subcutaneous emphysema following tonsillectomy and/or adenoidectomy.

\begin{tabular}{|c|c|c|c|c|c|c|c|}
\hline Authors & Year & Sex/Age(yrs) & Symptoms & Treatments & Surgery & Technique & Resolving Time \\
\hline Baker LJ [16] & 1936 & $\mathrm{~F} / 27$ & $\begin{array}{l}\text { Cough, face and } \\
\text { neck swelling, }\end{array}$ & Observation & Tonsillectomy & Cold steel & $6 \mathrm{~d}$ \\
\hline $\begin{array}{c}\text { Silverman et al. } \\
\text { [17] }\end{array}$ & 1950 & $\mathrm{M} / 8$ & $\begin{array}{l}\text { Neck swelling, } \\
\text { dyspnea }\end{array}$ & Antibiotics & Tonsillectomy & Cold steel & $?$ \\
\hline $\begin{array}{c}\text { Knutson and } \\
\text { Ouellete [7] }\end{array}$ & 1954 & M/6 & $?$ & Antibiotics & Tonsillectomy & Cold steel & $1 w k$ \\
\hline $\begin{array}{c}\text { Ferguson et al. } \\
{[15]}\end{array}$ & 1955 & $\mathrm{~F} / 4$ & $\begin{array}{c}\text { Dyspnea, } \\
\text { abdominal } \\
\text { distention, } \\
\text { heart was } \\
\text { shifted }\end{array}$ & $\begin{array}{l}\text { Thoracotomy, } \\
\text { transfusion }\end{array}$ & Tonsillectomy & Cold steel & $10 \mathrm{~d}$ \\
\hline Pratt et al. [18] & 1958 & $\mathrm{~F} / 9$ & $?$ & Thoracotomy & Tonsillectomy & $?$ & $6 \mathrm{~d}$ \\
\hline $\begin{array}{l}\text { Prupas and } \\
\text { Fordham [19] }\end{array}$ & 1976 & $\mathrm{M} / 22$ & $\begin{array}{c}\text { Dyspnea, } \\
\text { anterior chest } \\
\text { pain }\end{array}$ & Observation & Tonsillectomy & Cold steel & $?$ \\
\hline Vos et al. [10] & 1995 & $\mathrm{~F} / 5$ & $\begin{array}{l}\text { Abdominal } \\
\text { distension }\end{array}$ & $\begin{array}{c}\text { Needle } \\
\text { decompression }\end{array}$ & Tonsillectomy & $?$ & $?$ \\
\hline $\begin{array}{l}\text { Braverman et } \\
\text { al. [20] }\end{array}$ & 1997 & $\mathrm{~F} / 22$ & $\begin{array}{l}\text { Sore throat, } \\
\text { chest pain }\end{array}$ & Observation & Tonsillectomy & Cold steel & $1 \mathrm{wk}$ \\
\hline $\begin{array}{c}\text { Miman et al. } \\
{[11]}\end{array}$ & 2001 & $\mathrm{M} / 11$ & Neck swelling & Antibiotics & Adenotonsillectomy & Cold steel & $1 d$ \\
\hline $\begin{array}{c}\text { Watanabe et al. } \\
\text { [21] }\end{array}$ & 2001 & $\mathrm{M} / 24$ & $\begin{array}{l}\text { Face and neck } \\
\text { swelling }\end{array}$ & Antibiotics & Tonsillectomy & $?$ & $6 d$ \\
\hline $\begin{array}{c}\text { Nishino et al. } \\
{[14]}\end{array}$ & 2002 & $\mathrm{~F} / 55$ & $\begin{array}{l}\text { Face and neck } \\
\text { swelling }\end{array}$ & Antibiotics & Tonsillectomy & $?$ & $1 \mathrm{wk}$ \\
\hline \multirow[t]{2}{*}{ Gillot et al. [22] } & 2002 & $\mathrm{~F} / 52$ & $\begin{array}{l}\text { Chest pain, neck } \\
\text { swelling }\end{array}$ & $\begin{array}{l}\text { ICU, intubation, } \\
\text { antibiotics, }\end{array}$ & Tonsillectomy & Cold steel & $8 d$ \\
\hline & & $\mathrm{F} / 43$ & $\begin{array}{l}\text { Sore throat, } \\
\text { dysphagia, } \\
\text { fever, neck } \\
\text { swelling, chest } \\
\text { pain, purulent } \\
\text { phlegm }\end{array}$ & $\begin{array}{l}\text { ICU, antibiotics, } \\
\text { Reintubation } \\
\text { \& drainage of } \\
\text { pharyngeal/ } \\
\text { mediastinal } \\
\text { collection }\end{array}$ & Tonsillectomy & $?$ & $15 \mathrm{~d}$ \\
\hline $\begin{array}{c}\text { Marioni et al. } \\
\text { [23] }\end{array}$ & 2003 & $\mathrm{~F} / 34$ & Face swelling & Antibiotics & Tonsillectomy & $\begin{array}{l}\text { Cold steel with } \\
\text { bipolar }\end{array}$ & 30 hours \\
\hline $\begin{array}{c}\text { Yammine et al. } \\
{[24]}\end{array}$ & 2004 & $\mathrm{M} / 36$ & $\begin{array}{l}\text { pain and } \\
\text { swelling at } \\
\text { the OP site, } \\
\text { dysphagia }\end{array}$ & Antibiotics & Tonsillectomy & Cold steel & $1 w k$ \\
\hline Stewart et al. [9] & 2004 & $\mathrm{~F} / 22$ & Face swelling & Antibiotics & Tonsillectomy & Electrodissection & $3 w k s$ \\
\hline Shine et al. [25] & 2005 & $\mathrm{~F} / 7$ & $\begin{array}{l}\text { Neck pain, } \\
\text { limited neck } \\
\text { movement }\end{array}$ & $\begin{array}{c}\text { Oxygen, } \\
\text { antibiotics, ICU }\end{array}$ & Adenotonsillectomy & Electrodissection & $6 \mathrm{~d}$ \\
\hline $\begin{array}{c}\text { Penerari et al. } \\
{[26]}\end{array}$ & 2005 & $\mathrm{~F} / 31$ & Stridor, dyspnea & $\begin{array}{l}\text { Suture and close } \\
\text { muscle planes, } \\
\text { tracheostomy, } \\
\text { Antibiotics }\end{array}$ & Tonsillectomy & $?$ & $5 d$ \\
\hline Lima et al. [27] & 2005 & $\mathrm{M} / 25$ & Neck swelling & Antibiotics & Tonsillectomy & $?$ & $10 \mathrm{~d}$ \\
\hline Kim et al. [28] & 2008 & $\mathrm{~F} / 36$ & Neck swelling & Antibiotics & Tonsillectomy & Electrodissection & $1 \mathrm{wk}$ \\
\hline Hung et al. [29] & 2008 & $\mathrm{M} / 37$ & Neck swelling & Antibiotics & Tonsillectomy & $?$ & $1 \mathrm{wk}$ \\
\hline Bizaki et al. [30] & 2013 & $\mathrm{~F} / 29$ & $\begin{array}{l}\text { Sore throat, face } \\
\text { swelling }\end{array}$ & Antibiotics & Tonsillectomy & Electrodissection & $6 \mathrm{~d}$ \\
\hline
\end{tabular}


Global Journal of Otolaryngology

\begin{tabular}{|c|c|c|c|c|c|c|c|}
\hline $\begin{array}{l}\text { Koukoutsis et } \\
\text { al. [31] }\end{array}$ & 2013 & $\mathrm{~F} / 21$ & $\begin{array}{l}\text { Cough, emesis, } \\
\text { pain and neck } \\
\text { swelling }\end{array}$ & Antibiotics & Tonsillectomy & $\begin{array}{l}\text { Cold steel with } \\
\text { electrodissection }\end{array}$ & $1 \mathrm{wk}$ \\
\hline $\begin{array}{c}\text { AlJaber and } \\
\text { AlHarethy [32] }\end{array}$ & 2013 & $\mathrm{M} / 43$ & $\begin{array}{c}\text { Neck swelling, } \\
\text { odynophagia }\end{array}$ & Antibiotics & Tonsillectomy & Cold steel & $6 \mathrm{~d}$ \\
\hline $\begin{array}{c}\text { Tran and } \\
\text { Littlefield [33] }\end{array}$ & 2013 & $\mathrm{~F} / 30$ & None & Antibiotics & Tonsillectomy & Electrodissection & $?$ \\
\hline $\begin{array}{l}\text { Yelnoorkar and } \\
\text { Issing [34] }\end{array}$ & 2013 & $\mathrm{M} / 18$ & $\begin{array}{l}\text { Face and neck } \\
\text { swelling }\end{array}$ & Antibiotics & Tonsillectomy & Bipolar diathermy & $3 d$ \\
\hline $\begin{array}{c}\text { Crosbie and } \\
\text { Kunanandam } \\
\text { [35] }\end{array}$ & 2016 & $\mathrm{~F} / 12$ & $\begin{array}{l}\text { Dysphagia, } \\
\text { odynophagia } \\
\text { and neck } \\
\text { swelling }\end{array}$ & Antibiotics & Tonsillectomy & Harmonic scalpel & $3 d$ \\
\hline Erol et al. [36] & 2016 & $\mathrm{M} / 4$ & $\begin{array}{l}\text { Face swelling, } \\
\text { gagging, } \\
\text { vomiting }\end{array}$ & Observation & Tonsillectomy & Cold steel & $6 d$ \\
\hline Present case & 2016 & $\mathrm{M} / 11$ & $\begin{array}{l}\text { neck pain, } \\
\text { stiffness, } \\
\text { dysphagia }\end{array}$ & Antibiotics & Adenoidectomy & Cold steel & $1 \mathrm{wk}$ \\
\hline $\begin{array}{c}\text { Saravakos et al. } \\
\text { [37] }\end{array}$ & 2017 & $\mathrm{M} / 21$ & Neck swelling & $\begin{array}{l}\text { Antibiotics, } \\
\text { cough } \\
\text { suppressants, } \\
\text { laxatives }\end{array}$ & Tonsillectomy & $\begin{array}{l}\text { Cold steel with } \\
\text { bipolar }\end{array}$ & $10 \mathrm{~d}$ \\
\hline
\end{tabular}

Harmonic scalpel was used for only one case of tonsillectomy. For 2 patients adenotonsillectomy was performed, one by electrodessication whereas the other by cold steel technique. In our case adenoidectomy was performed using cold steel method. The surgical technique in the remaining 8 was not indicated. Most of the patients presented with dyspnea, dysphagia, neck swelling and chest pain. Out of 30 patients, 24 patients were treated conservatively, and 6 cases required aggressive treatment of the subcutaneous emphysema and pneumomediastinum (2 patients required thoracotomy, 1 case involved tracheostomy, 1 patient needed needle decompression, 1 patient was re-intubated in ICU and 1 patient underwentre-intubation and external cervicectomy). Although none of the 30 patients died, subcutaneous emphysema and pneumomediastinum may result in fatal complications such as tension pneumomediastinum that may lead to circularity arrest secondary to accumulation of air which in return compresses the heart and decreases cardiac output [12]. Patients undergoing adenoidectomy and/or tonsillectomy should be monitored closely, and follow-up observation is required. Management of subcutaneous emphysema is generally conservative, it is selflimited condition in most cases. Supplemental oxygen may facilitate absorption of nitrogen from air accumulating in the emphysematous cavity in a favorable downward concentration gradient, by which recovery from emphysema is hastened [11]. Patients should be started on intravenous hydration and analgesia where odynophagia is significant. Any activities that may increase upper airway pressure such as coughing, vomiting and straining should be avoided until resolution of emphysema, antitussive, antiemetic, and stool softener medications may be used when indicated. Broad-spectrum antibiotics should be administered to prevent contamination and infection from oral cavity. If dehiscence of pharyngeal mucosa is demonstrated, pharyngeal mucosa should be sutured to prevent emphysema progression and the entry of opportunistic bacteria [14]. All 30 patients improved on average 7.1 days (range, 30 hours to 3 weeks).

\section{Conclusion}

This unusual case should increase awareness that subcutaneous emphysema and pneumomediastinum may present after adenoidectomy surgery alone. Since our case consider as the only one reported in the English literature. Clinicians should have a heightened sense of awareness, especially with any mention of breathing difficulties or crepitus, they must assess the chest to roll out pneumomediastinum. In addition, because of the increased risk of developing either of these conditions with a positive pressure event, providers should help to ensure smooth emergences by working closely with their anesthesia colleagues. There should be good communication to ensure the patient does not wake before completion of surgery, and the airway should be suctioned with an orogastric tube to avoid laryngeal irritation upon emergence [29]. Finally, close observation of the patients is mandatory, it will help ensure these potential complications do not develop into life-threatening situations [30-37].

\section{Acknowledgment}

This case report did not receive any specific grant from funding agencies in the public, commercial, or not-for-profit sectors.

\section{References}

1. Tomkinson A, Harrison W, Owens D, Fishpool S, Temple M, et al. (2012) Postoperative hemorrhage following adenoidectomy. Laryngoscope 122(6): 1246-1253.

2. Thomas K, Boeger D, Buentzel J, Esser D, Hoffmann K, et al. (2013) Pediatric adenoidectomy: a population based regional study on epidemiology and outcome. Int J Pediatr Otorhinolaryngol 77(10): 1716-1720. 


\section{Global Journal of Otolaryngology}

3. (2012) Adjuvant adenoidectomy in persistent bilateral otitis media with effusion: hearing and revision surgery outcomes through 2 years in the target randomized trial. Clin Otolaryngol 37: 107-116.

4. Mathew R, Asimacopoulos E, Walker D, Gutierrez T, Valentine P, et al (2012) Analysis of clinical negligence claims following tonsillectomy in England 1995 to 2010. Ann Otol Rhinol Laryngol 121: 337-340.

5. Witzel MA, Rich RH, Margar Bacal F, Cox C (1986) Velopharyngeal insufficiency after adenoidectomy: an 8year review. Int J Pediatr Otorhinolaryngol 11(1): 15-20.

6. Wan DC, Kumar A, Head CS, Katchikian H, Bradley JP, et al. (2010) Amelioration of acquired nasopharyngeal stenosis, with bilateral Z pharyngoplasty. Ann Plast Surg 64:747-750.

7. Knutson RC, Ouellette AJ (1954) Subcutaneous emphysema following tonsillectomy and adenoidectomy. Minn Med 37(12): 877-879.

8. Leong SC, Karkos PD, Papouliakos SM, Apostolidou MT (2007) Unusual complications of tonsillectomy: a systematic review. Am J Otolaryngol 28(6): 419-422.

9. Stewart AE, Brewster DF, Bernstein PE (2004) Subcutaneous emphysema and pneumomediastinum complicating tonsillectomy. Arch Otolaryngol Head Neck Surg 130:1324-1327.

10. Vos GD, Marres EH, Heineman E, Janssens M (1995) Tension pneumoperitoneum as an early complication after adenotonsillectomy. J Laryngol Otol 109(5): 440-441.

11. Miman MC, Ozturan O, Durmus M, Kalcioglu MT, Gedik E,et al. (2001) Cervical subcutaneous emphysema: an unusual complication of adenotonsillectomy. Paediatr Anaesth 11: 491-493.

12. Friedman O, Chidekel A, Lawless ST, Cook SP (1999) Postoperative bilevel positive airway pressure ventilation after tonsillectomy and adenoidectomy in children: a preliminary report. Int J Pediatr Otorhinolaryngol 51: 177-180.

13. Hampton SM, Cinnamond MJ (1997) Subcutaneous emphysema as a complication of tonsillectomy J Laryngol Otolaryngol 111(11): 1077 1078.

14. Nishino H, Kenmochi M, Kasugai S, Okada T, Ohashi T, et al. (2003) Subcutaneous emphysema secondary to tonsillectomy: a case report. Auris Nasus Larynx 30: 135-136.

15. Ferguson CC, Mcgarry PM, Beckman IH, Broder M (1955) Surgical emphysema complicating tonsillectomy and dental extraction. Can Med Assoc J 72: 847-848.

16. Baker LJ (1936) Subcutaneous emphysema complicating tonsillectomy. Can Med Assoc J 34: 670- 676.

17. Silverman JJ, Talbot TJ, Mc Clean RW (1953) Mediastinal emphysema following tonsillectomy. Dis Chest 23(4): 397-402.

18. Pratt LW, Hornberger HR, Moore VJ (1962) Mediastinal emphysema complicating tonsillectomy and adenoidectomy. Ann Otol Rhinol Laryngol 71:158-169.

19. Prupas HM, Fordham SD (1977) Emphysema secondary to tonsillectomy. Laryngoscope 87: 1134-1136.

20. Braverman I, Rosenmann E, Elidan E (1997) Closed rhinolalia as symptom of pneumomediastinum after tonsillectomy: a case report and literature review. Otolaryngol Head Neck Surg 116(4): 551-553.
21. Watanabe K, Kunitomo M, Yamauchi Y, Kimura M, Masuno S, et al (2004) Subcutaneous emphysema after tonsillectomy: a case report. J Nippon Med Sch 71: 111-113.

22. Gillot C, Tombu S, Crestani V, Huvelle P, Moreau P, et al. (2005) Subcutaneous emphysema and mediastinitis: unusual complications of tonsillectomy. B-ENT 1(4): 197-200.

23. Marioni G, Filippis C, Tregnaghi A, Gaio E, Staffieri A, et al. (2003) Cervical emphysema and pneumomediastinum after tonsillectomy: It can happen. Otolaryngol Head Neck Surg 128: 298-300.

24. Yammine NV, Alherabi A, Gerin Lajoie J (2004) Post-tonsillectomy subcutaneous emphysema and pneumomediastinum. J Otolaryngol 33: 403-404.

25. Shine NP, Sader C, Coates H (2005) Cervicofacial emphysema and pneumomediastinum following pediatric adenotonsillectomy: A rare complication. Int J Pediatr Otorhinolarymgol 69: 1579-1582.

26. Panerari AC, Soter AC, Silva FL, De Oliveira LF, Neves MD, et al. (2005) Onset of subcutaneous emphysema and pneumomediastinum after tonsillectomy: a case report. Braz J Otorhinolaryngol 71(1): 94-96.

27. Lima WL, Correa NS, De Campos JL, Navarro PM, Correia LO, et al. (2005) Subcutaneous emphysema after tonsillectomy: case report. Rev Bras Anestesiol 55(4): 441-444.

28. Kim JP, Park JJ, Kang HS, Song MS (2010) Subcutaneous emphysema and pneumomediastinum after tonsillectomy. Am J Otolaryngol-Head Neck Med Surg 31: 212-215.

29. Hung MH, Shih PY, Yang YM, Lan JY, Fan SZ, et al. (2009) Cervicofacial subcutaneous emphysema following tonsillectomy: implications for anesthesiologists. Acta Anaesthesiol Taiwan 47: 134-137.

30. Bizaki A, Kääriäinen J, Harju T, Rautiainen M (2014) Facial subcutaneous emphysema after tonsillectomy. Head Face Med 10: 11

31. Koukoutsis G, Balatsouras DG, Ganelis P, Fassolis A, Moukos A, et al. (2013) Subcutaneous emphysema and pneumomediastinum after tonsillectomy. Case Rep Otolaryngol 2013: 3.

32. Al Jabr I, Al Harethy S (2014) Cervicofacial subcutaneous emphysema, a rare complication of tonsillectomy. Egyptian J of Ear Nose Throat and Allied Sciences 15(1): 49-51.

33. Tran DD, Littlefield PD (2015) Late presentation of subcutaneous emphysema and pneumomediastinum following elective tonsillectomy. Am J Otolaryngol 36(2): 299-302.

34. Yelnoorkar S and Issing W (2014) Cervicofacial Surgical Emphysema following Tonsillectomy. Case Rep Otolaryngol 2014: 2.

35. Crosbie R A, Kunanandam T (2017) Cervicofacial emphysema following Harmonic scalpel tonsillectomy: case report and comprehensive review of the literature. J Laryngol Otol 131: 177-80.

36. Erol 0, Aydin E (2016) A rare complication of tonsillectomy: subcutaneous emphysema. Turk Arch Otorhinolaryngol 54(4): 172-174.

37. Saravakos P, Taxeidis M, Kastanioudakis I, Oliver Reichel (2018) Subcutaneous emphysema as a complication of tonsillectomy: A systematic literature review and case report. Iran J Otorhinolaryngol 30(96): 3-10. 
Chis work is licensed under Creative (C) Commons Attribution 4.0 License (CC) DYI: 10.19080/GJO.2019.18.556000
Your next submission with Juniper Publishers will reach you the below assets

- Quality Editorial service

- Swift Peer Review

- Reprints availability

- E-prints Service

- Manuscript Podcast for convenient understanding

- Global attainment for your research

- Manuscript accessibility in different formats

( Pdf, E-pub, Full Text, Audio)

- Unceasing customer service

Track the below URL for one-step submission https://juniperpublishers.com/online-submission.php 